Article

\title{
Corporate Social Responsibility Disclosure, Media Reports, and Enterprise Innovation: Evidence from Chinese Listed Companies
}

\author{
Shilei $\mathrm{Wu}^{1}{ }^{1}$, Hongjie Zhang ${ }^{1, *}$ and Taoyuan Wei ${ }^{2, *}$ (1) \\ 1 School of Economics, Shandong University of Technology, Zibo 255000, China; leishiwuwushilei@126.com \\ 2 CICERO Center for International Climate Research, 0318 Oslo, Norway \\ * Correspondence: zhanghongjie163163@163.com (H.Z.); taoyuan.wei@cicero.uio.no (T.W.)
}

check for updates

Citation: Wu, S.; Zhang, H.; Wei, T. Corporate Social Responsibility Disclosure, Media Reports, and Enterprise Innovation: Evidence from Chinese Listed Companies. Sustainability 2021, 13, 8466 . https://doi.org/10.3390/su13158466

Academic Editor: David K. Ding

Received: 18 June 2021

Accepted: 26 July 2021

Published: 29 July 2021

Publisher's Note: MDPI stays neutral with regard to jurisdictional claims in published maps and institutional affiliations.

Copyright: (c) 2021 by the authors. Licensee MDPI, Basel, Switzerland. This article is an open access article distributed under the terms and conditions of the Creative Commons Attribution (CC BY) license (https:/ / creativecommons.org/licenses/by/ $4.0 /)$.

\begin{abstract}
Given the limited response of enterprises to China's national policy on the compulsory disclosure of corporate social responsibility (CSR), a deviation has occurred between policy orientation and reality. To explore the reasons behind this deviation, we investigated whether different types of media reports play an intermediary role in the process of CSR affecting corporate innovation based on the data of the companies listed on China's Shenzhen Stock Exchange and Shanghai Stock Exchange from 2010 to 2019. The results show that the disclosure of CSR by the listed companies can significantly promote corporate innovation, which provides theoretical support for the national compulsory disclosure of CSR. Newspaper media reports and online media reports not only directly promote corporate innovation but also form a positive mediation path in the CSR disclosure and the promotion of corporate innovation. Further analysis shows that, among the five aspects of CSR, the disclosure of employee responsibility had the greatest effect on the corporate innovation, whereas the disclosure of social contribution responsibility only had a short-term inhibitory effect. Both newspaper media and online media reports on CSR disclosure were beneficial to corporate innovation. Positive and neutral reports may play the role of media governance to promote corporate innovation, whereas negative reports can restrain corporate innovation due to the market pressure effect produced by them, which also provides the basis for media supervision by the state.
\end{abstract}

Keywords: corporate social responsibility (CSR); media coverage; listed company; enterprise innovation; intermediary role

\section{Introduction}

Compulsory CSR disclosure has been proposed by many countries, but this policy has not been promoted effectively. Since 2005, the World Bank has started to collect the CSR disclosure information of enterprises in 233 countries and has graded them in accordance with the 10-point system, where a higher score indicates more active CSR disclosure. According to the World Bank data, only 41 countries obtained more than six points in 2005, accounting for only $18 \%$ of all involved countries; in 2019, the countries obtaining more than six points increased to 97 , accounting for $42 \%$ of the total. In terms of China, the China Securities Regulatory Commission (CSRC), Shenzhen Stock Exchange, and Shanghai Stock Exchange issued a notice in December 2008 to force listed companies to disclose their CSR reports. In the Third Plenary Session of the 18th Communist Party of China (CPC) Central Committee, social responsibility is listed as one of the six primary tasks of enterprises. In 2014, the China Corporate Social Responsibility Evaluation Standard was issued by the central government, and the 19th CPC National Congress required the enterprises to take social responsibility. However, as of December 2019, only 1006 enterprises among the 3939 enterprises listed on China's Shenzhen and Shanghai stock markets had fully released relevant social responsibility reports, accounting for just $26 \%$ of the total. The policy orientation and the actual situation differed, which resulted in the social and economic 
benefits of CSR disclosure becoming a hot research topic. With the outbreak of COVID-19, how the enterprises, as the main undertakers of social production and services, should assume CSR has also become the focus of public attention. Innovation is not only the source of economic development but also serves as the core of corporate competitiveness. The impact of CSR disclosure on corporate innovation has not yet been fully elucidated by academia; some scholars have found that the performance of social responsibility by enterprises may be unfavorable for corporate innovation, because they occupy relevant R\&D resources [1]. However, other scholars have stated that the active disclosure of social responsibility by enterprises can meet the demands of external stakeholders and obtain more resources support, thus promoting corporate innovation [2-4].

In view of this debate, most researchers only studied the direct internal relationship between CSR disclosure and corporate innovation, and the role of external stakeholders in this relationship has seldom been considered. With the advent of the information age, the impact of media reports, an external stakeholder, on the enterprises, cannot be ignored. The governance role of media reports on corporate taxation and internal finance has been verified, and their role in the transmission of enterprise information is also increasing [5-7]. Ahern and Sosyura [8] found that pertinent media reports can boost public confidence and improve corporate image, but exaggerated and maliciously discredited false reports would negatively impact the reputation of the enterprise [9]. For example, the Report on Cotton in Xinjiang, China in 2021 named several giant clothing and textile enterprises and impacted the status of clothing enterprises globally. The external supervision effect of media reports has been verified, but the relationship between media reports and corporate innovation has not been clarified. Additionally, when the CSR disclosure plays a role in corporate innovation, whether media reports participate in it and what role they play are unknown.

Hence, in this study, we attempted to incorporate media reports into the research framework of the impact of CSR disclosure on corporate innovation. The contributions of this study to the literature lie in four aspects: First, new evidence from China was obtained by investigating the impact of CSR disclosure and media reports on corporate innovation; in particular, we introduced the mediation path of different types of media reports. The new evidence has reference value for policy makers to optimize resource allocation and enhance the performance of corporate innovation. Second, the research results of this paper support the theory of the positive effect of CSR disclosure and media reports on corporate innovation, and are thus of guiding significance to help enterprise managers actively perform CSR disclosure. Third, the further investigation of dividing newspaper media reports and online media reports into positive, neutral, and negative reports helps with interpreting and expanding the role of media reports in the capital market in more detail. For example, in most of the previous studies, it was thought that media reports would promote corporate innovation (corporate governance hypothesis), but the inhibiting effect of media reports on corporate innovation was overlooked. Our study is an extension of the market pressure hypothesis, and provides a theoretical basis for China to conduct media supervision and governance and optimize the innovation environment. Fourth, unlike previous studies that typically focused on the disclosure of corporate profits and finances, we analyzed corporate innovation from a non-financial external perspective based on data collected from the micro-individual enterprises listed on China's Shenzhen Stock Exchange and Shanghai Stock Exchange. The CSR disclosure and media reports both used data from third-party authoritative agencies; thus, the conclusions are more objective, accurate, and interpretative than those of studies based on the internal reports of relevant enterprises.

\section{Literature Review}

\subsection{CSR Disclosure and Corporate Innovation}

The impact of CSR disclosure on innovation was mostly considered by academia from the aspects of information asymmetry and agency problems [10,11]. Lin et al. [10] found that if there is higher CSR and a lower degree of information asymmetry, CSR disclosure 
can convey information to the external environment, disclose enterprise risks, reduce the adverse choices of the public, and alleviate the problem of information asymmetry [12]. Hu et al. [13] found from the data of Chinese A-share listed companies that CSR disclosure can alleviate the problem of information asymmetry between enterprises and the external environment, broaden the financing channels, and improve the sustainability of innovation. Costa et al. [14] similarly concluded that the disclosure of social responsibility by enterprises can make it difficult for managers to hide negative information about the company, passively create a communication effect with the external environment, increase the transparency of the company's investments, and help the investors understand the company's operation status [15], thus alleviating the problem of entrustment and agency. Additionally, some scholars found that CSR disclosure is highly consistent with innovation behavior, both of which are activities with long-term value. Social responsibility disclosure can enhance investors' attention and understanding of such activities, so that the enterprises can obtain investors' support for innovation behavior [16]. Other scholars demonstrated the positive impact of CSR disclosure on corporate innovation from the perspective of patent output [17].

The information hiding hypothesis was first described by Hutton et al. [18], who pointed out that the managers of a company, in reality, choose to benefit themselves first without considering the overall interests of the company. In addition, the enterprises tend to disclose only positive information that is beneficial to the company, and conceal the actual operation of the company [19].The internal employees of the enterprise may also engage in some opportunistic behaviors of fulfilling social responsibility by taking advantage of people being highly concerned about whether the enterprise is fulfilling its social responsibility, so that people only pay attention to the positive news that is beneficial to the development of the enterprise, but ignore the negative news about the enterprise that may exist at the same time, thus achieving the purpose of diverting the attention of the public [20]. For example, CR Land, which was awarded the title of the most qualityoriented city operator, was also subjected to collective complaints by the owners for being suspected of false propaganda; Tsingtao Brewery, which was a giant in the beer industry, was also caught in the incidents known as quality gate and environmental protection gate for the many times when it was actively involved in various public welfare undertakings. Under such good news disclosure, CSR disclosure became a whitewashing means for an enterprise to maintain its image and a self-interest tool to hide misconducts [21,22]. CSR disclosure was not conducive to or even inhibitive of corporate innovation.

\subsection{CSR Disclosure and Media Reports}

Media reports are the discoverers, processors, and disseminators of information. Especially in today's society with convenient news and information, media reports have become the most important channel for the public to obtain corporate information [23]. Enterprises and media are interdependent: on the one hand, the media need corporate news as support for circulation and click-through rate; conversely, enterprises need media reports to enhance their public image. Hayes and Carr [24] found that increasing amounts of CSR work are carried out through the media, which is often the key to achieving the CSR goals of organizations. Lu et al. [25] found from China's data that the enterprises with higher social responsibility index tend to attract more media reports [26], and the enterprises use media reports as a packaging tool to disclose their social responsibility [27]. Despite the differences in the establishment of media departments in the east and west, with mixed praise and criticism, Chinese users generally think that Chinese media are independent from the enterprises and investors and enjoy a high level of public trust. Through the study of online media reports on corporate donations, $\mathrm{Xu}$ et al. [28] found that the media, as a supervisor of social activities, plays a correct role in guiding public opinion, paying more attention to the incidents related to CSR, and exposing fraud and the illegal acts of enterprises in a timely manner. Huang et al. [20] found that based on the strong demand of the public for whether enterprises should disclose corresponding 
social responsibility information, newspaper media conduct in-depth follow-up reports on whether the enterprises should disclose and fulfill their social responsibility commitments.

\subsection{Media Reports and Corporate Innovation}

Corporate innovation is the result of an internal and external two-way linkage operation. Among the external influencing factors, media reports play an indirect role in corporate innovation. Using China's data test, He and Zhao [29] found that media reports have a positive effect on corporate innovation. After the media reports were divided into newspaper media reports and online media reports, this promotion effect still existed [30]. The corporate governance hypothesis states that media, as a disseminator of information, increase the transparency of enterprise information and market information, and the existence of the media increased the investors' attention to enterprise information [31,32]. Positive news reports demonstrate the development prospects of enterprises, their media role avoids the undervaluation of enterprises and strengthens the investment confidence of small and medium shareholders. Investors have a greater willingness to invest [33], thus alleviating the financial constraints required for innovative behavior [34]. It was found that a reputation mechanism exists [35], which relies on the external media. Managers are willing to trade off indulging in a quiet life and their own future to strive for innovation and achievements [5]. Negative news reports lead to pressure due to external public opinion [36]. The managers of the enterprises also implement corresponding governance measures to increase innovation willingness. Moreover, the supervision effect caused by media reports has a deterrent effect on managers [37]. Not only the investor's supervision but also the government-related supervision departments restrain the innovation behavior of managers to avoid their speculative behavior, thus improving the corporate innovation performance of enterprises [38].

According to the market pressure hypothesis, corporate innovation is a long-term activity, whereas the media pays attention to the performance reflected in the short-term financial statements [23]. To achieve the goals of shareholders and investors, managers of enterprises may choose non-action. This complies with the view of modern management theory: managers do not bother to find the optimal solutions for possible risks, but choose the solutions that satisfy the majority, and this short-sighted behavior of managers hinders the innovation of enterprises [39]. Additionally, the unpredictability of the results of innovation activities and the vicious competition among the media may focus more on the sensation of news rather than its accuracy. Whether in newspaper or online media, Yang et al. [40] found that Chinese media has a tendency to scandalize, emotionalize, and sensationalize the reports, such as the famous $21 \mathrm{CBH}$ fake news extortion case. Zhang and Peng [32] also found that in the media ecology oriented by negative and sensational reports, the failure of R\&D would result in the enterprise becoming the target of public criticism [37], and the media also takes advantage of this to amplify the negative effects of failures. At this time, the media reports on a company's innovation failures are undoubtedly devastating, so managers of enterprises adopt a cautious attitude toward innovation behavior [11,39].

\section{Model and Method}

\subsection{Test Process and Hypothesis}

The impact of CSR on corporate innovation is not yet known. It is still necessary to prove whether media reports exert pressure on corporate innovation or produce a governance effect. CSR performance may attract the attention of the media and increase media reports. Based on this, we constructed hypotheses $\mathrm{H} 1$ and H2:

Hypothesis 1 (H1). When CSR disclosure plays a role in corporate innovation, newspaper media reports play an intermediary role.

Hypothesis $2 \mathbf{( H 2 ) . ~ W h e n ~ C S R ~ d i s c l o s u r e ~ p l a y s ~ a ~ r o l e ~ i n ~ c o r p o r a t e ~ i n n o v a t i o n , ~ o n l i n e ~ m e d i a ~}$ reports play an intermediary role. 
However, whether the mediating effect is positive or negative needs to be tested using specific data. According to the test process of the mediating effect, the framework followed in this study is shown in Figure 1. The process of mediation testing also included the test of the impact of CSR disclosure on corporate innovation, and the newspaper media reports and online media reports on corporate innovation.

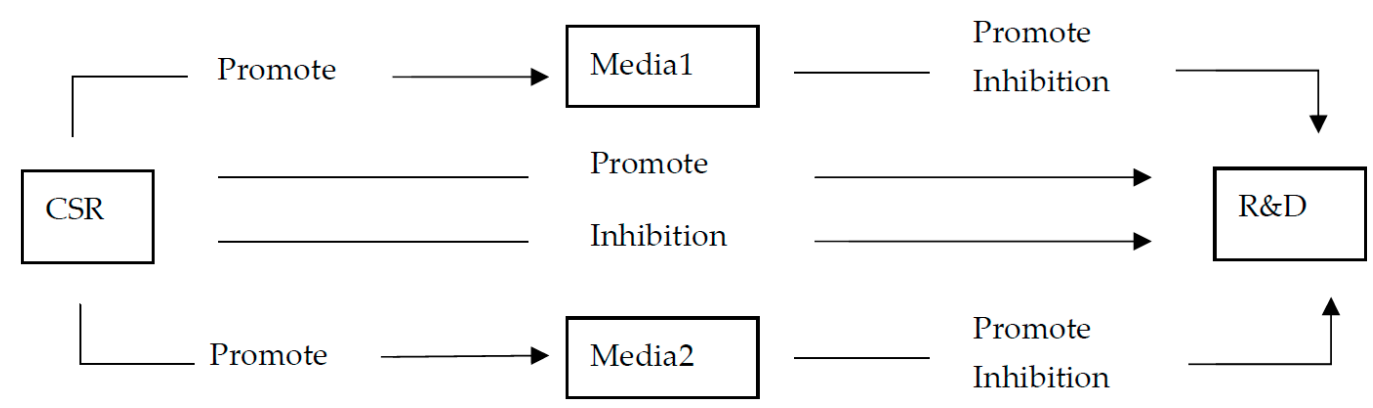

Figure 1. Flow chart of hypothesis testing.

\subsection{Sample Selection and Processing}

In this study, all the companies listed on the Shenzhen Stock Exchange and Shanghai Stock Exchange from 2010 to 2019 were used as the initial samples. The two stock exchanges release the basic information about their listed companies, such as the geographical location of the company, information about the company's legal person, the nature of the company, various financial indicators, the types of shares issued, dividends, expenses, and income. All of these companies are headquartered in China and distributed among the 31 provinces and cities in China. Therefore, this dataset is often collectively referred to as the Chinese listed companies in the same type of research. Notably, there were no enterprises headquartered in Hong Kong, China in these samples. Therefore, the analysis in this study only focused on the reality of mainland China. Learning from the practices of other scholars [11,15], the data were processed as follows: 1 . eliminating the samples with financial abnormalities such as ST and *ST and companies listed in the financial sector; 2. eliminating the samples with missing values of variables; 3 . eliminating the samples with a CSR index score of less than $0 ; 4$. performing $1 \%$ Winsorize processing. After the processing of the initial data, 2146 companies remained, and 8264 annual observation values of companies were generated. Stata 15 was chosen as the software for data operation and follow-up inspection.

\subsection{Index Selection and Data Source}

CSR disclosure was measured using the CSR index. The third-party authoritative agencies for rating CSR included RKS and Hexun, and the CSR index used in this study was from Hexun because, first, RKS initially only calculated the statistics of the enterprises that actively disclosed their CSR reports, and the coverage of the samples was relatively narrow; second, Hexun set up the scoring standards for rating based on a weighting of $30 \%, 15 \%, 15 \%, 20 \%$, and $20 \%$ from the five aspects of shareholder responsibility, employee responsibility, supplier responsibility, environmental responsibility, and social contribution responsibility, respectively, which is more accurate and objective.

The newspaper media reports and online media reports data were obtained from CFND, which covers all financial media in China. The data included the news data from more than 600 major newspapers, including eight major Chinese financial newspapers: China Securities Journal, Shanghai Securities, China Business News, 21st Century Business Herald, China Business Journal, The Economic Observer, The Securities Daily, and Securities Times; more than 500 other important newspapers and publications: central newspapers, local morning newspapers, daily newspapers, evening newspapers, and other financial newspapers; the news reports from 20 mainstream online financial media, such as Hexun, Sina Finance, east money.com, Tencent Finance, Netease Finance, finance.ifeng.com, 
ce.cn, business.sohu.com, jrj.com.cn, 591hx.com, ftchinese.com, www.p5w.net, cnfol.com, cnstock.com, stockstar.com, caixin.com, www.thepaper.cn, yicai.com, finance. $21 \mathrm{cn} . c 0 m$, and caijing.com.cn; and more than 400 large and important websites, industry websites, or local websites.

The variables used to measure corporate innovation in academia were innovation input intensity and innovation output degree. Based on the research hypothesis, we directly considered their impact on the managers' willingness to innovate, and the outputs, such as the number of patents, required a certain transformation process, but the specific time could not be determined. Therefore, the innovation input intensity was chosen to measure the level of corporate innovation. In this study, we also used the number of patents to demonstrate the robustness of the conclusion.

Based on relevant studies on the listed companies [16], the remaining control variables were selected as follows: enterprise scale, growth, listed years, cash flow, asset-liability ratio, profitability, quantity of employees, capital intensity, nature of property rights, and executive shareholding ratio. These were included in virtual industrial variables and virtual time variables. Table 1 lists the variable symbols and their definitions.

Table 1. Description of variables used in this study.

\begin{tabular}{|c|c|c|}
\hline Variable & Symbol & Definition \\
\hline \multicolumn{3}{|l|}{ Core variable } \\
\hline R\&D intensity & R\&D & $\begin{array}{l}\text { Natural logarithm of the total investment amount for R\&D projects of } \\
\text { enterprise } i \text { in the } t^{\text {th }} \text { year }\end{array}$ \\
\hline CSR index & CSR & $\begin{array}{l}\text { Natural logarithm of the social responsibility index of enterprise } i \text { in the } t^{\text {th }} \\
\text { year released by Hexun }\end{array}$ \\
\hline Newspaper media reports & Media1 & $\begin{array}{l}\text { The number of newspaper media reports about enterprise } i \text { in the } t^{\text {th }} \text { year in } \\
\text { the CFND database is plus } 1 \text {, and then the natural logarithm is taken }\end{array}$ \\
\hline Online media reports & Media2 & $\begin{array}{l}\text { The number of online media reports about enterprise } i \text { in the } t^{\text {th }} \text { year in the } \\
\text { CFND database plus 1, and then the natural logarithm is taken }\end{array}$ \\
\hline \multicolumn{3}{|l|}{ Control variable } \\
\hline Nature of the property right & SOE & $\begin{array}{l}\text { The nature of enterprise } i \text { in the } t^{\text {th }} \text { year is assigned } 1 \text { for state-owned } \\
\text { enterprises; otherwise, } 0\end{array}$ \\
\hline Growth & Growth & Market value/asset replacement cost of enterprise $i$ in the $t^{\text {th }}$ year \\
\hline Listed years & Age & Duration of enterprise $i$ by the end of the $t^{\text {th }}$ year \\
\hline Cash flow & $\mathrm{CFO}$ & $\begin{array}{l}\text { Net cash flow from operating activities of enterprise } i \text { in the } t^{\text {th }} \text { year/total } \\
\text { assets in the } t^{\text {th }} \text { year }\end{array}$ \\
\hline Leverage & Lev & Total liabilities of enterprise $i$ in the $t^{\text {th }}$ year/total assets in the $t^{\text {th }}$ year \\
\hline Executive shareholding ratio & ESI & $\begin{array}{l}\text { Enterprise } i \text { with executive shareholding in the } t^{\text {th }} \text { year is assigned } 1 \text {; } \\
\text { otherwise, } 0\end{array}$ \\
\hline Return on assets & ROA & The net profit of enterprise $i$ in the $t^{\text {th }}$ year/total assets in the $t^{\text {th }}$ year \\
\hline Number of employees & Num & Number of employees in enterprise $i$ in the $t^{\text {th }}$ year \\
\hline Capital intensity & $\mathrm{CI}$ & The fixed assets of enterprise $i$ in the $t^{\text {th }}$ year/total assets in the $t^{\text {th }}$ year \\
\hline Enterprise size & Size & Natural logarithm of the total assets of enterprise $i$ in the $t^{\text {th }}$ year \\
\hline
\end{tabular}

\subsection{Model Design}

Regression Equation (1) was established to test the influence relation of CSR disclosure with corporate innovation:

$$
R \& D_{i t}=\alpha_{0}+\alpha_{1} C S R_{i t}+\sum \alpha_{i} \text { Controls }_{i t}+\text { Industry }+ \text { Year }+\varepsilon_{i t}
$$


Regression Equations (2) and (3) were established to test the influence relationship of newspaper media and online media reports with corporate innovation:

$$
\begin{aligned}
& R \& D_{i t}=\beta_{0}+\beta_{1} \text { Media }_{i t}+\sum \beta_{i} \text { Controls }_{i t}+\text { Industry }+ \text { Year }+\varepsilon_{i t} \\
& R \& D_{i t}=\eta_{0}+\eta_{1} \text { Media }_{i t}+\sum \eta_{i} \text { Controls }_{i t}+\text { Industry }+ \text { Year }+\varepsilon_{i t}
\end{aligned}
$$

Regression Equations (4)-(7) were established to determine the influence relationship of CSR with newspaper and online media reports and the mediation path, i.e., hypotheses $\mathrm{H} 1$ and $\mathrm{H} 2$ :

$$
\begin{gathered}
\text { Media }_{i t}=\varphi_{0}+\varphi_{1} C_{C S R_{i t}}+\sum \varphi_{i} \text { Controls }_{i t}+\text { Industry }+ \text { Year }+\varepsilon_{i t} \\
R \& D_{i t}=\gamma_{0}+\gamma_{1} C_{\text {CSR }}+\gamma_{2} \text { Media }_{i t}+\sum \gamma_{i} \text { Controls }_{i t}+\text { Industry }+ \text { Year }+\varepsilon_{i t} \\
\text { Media }_{i t}=\pi_{0}+\pi_{1} C S R_{i t}+\sum \pi_{i} \text { Controls }_{i t}+\text { Industry }+ \text { Year }+\varepsilon_{i t} \\
R \& D_{i t}=u_{0}+u_{1} C_{\text {CSR }}+u_{2} \text { Media }_{i t}+\sum u_{i} \text { Controls }_{i t}+\text { Industry }+ \text { Year }+\varepsilon_{i t}
\end{gathered}
$$

In Equations (1)-(7), $\alpha, \beta, \eta, \varphi, \gamma, \pi$, and $\mu$ are all estimated coefficients. Industry and Year are the virtual industrial variable and the virtual time variable, respectively, added to control the fixed industrial effect and time effect, and are random disturbance items.

\subsection{Test Results}

\subsubsection{Statistical Description Results}

The descriptive statistics of all variables are shown in Table 2, and the standard deviation of core variable $R \& D$ is 1.320 , indicating a significant difference in the innovation level of different enterprises in different years. The top, middle, and bottom quartile values of CSR are $2.969,3.166,3.328$, respectively, and the mean value is 3.179 , with small data differences, indicating the actual requirements of CSR disclosure were only met by about $25 \%$ of enterprises. The mean value of Media1 is 3.166 and the standard deviation is 1.234 , indicating a significant difference in the quantity of reports by newspaper media for different companies in different years. The mean value of Media2 is 5.039 and the standard deviation is 0.984 , indicating a significant difference in the quantity of reports by online media for different companies in different years. As shown by the quartile value, the mean value, and the standard deviation, the remaining control variables showed significant hierarchy, so we confirmed that the sample used in the study is easy to recognize and strongly applicable.

Table 2. Statistical description of all variables.

\begin{tabular}{ccccccc}
\hline Variable & $\begin{array}{c}\mathbf{1 / 4} \\
\text { Quartile }\end{array}$ & $\begin{array}{c}\mathbf{2} / \mathbf{4} \\
\text { Quartile }\end{array}$ & $\begin{array}{c}\mathbf{3 / 4} \\
\text { Quartile }\end{array}$ & $\begin{array}{c}\text { Mean } \\
\text { Value }\end{array}$ & $\begin{array}{c}\text { Standard } \\
\text { Deviation }\end{array}$ & $\begin{array}{c}\text { Observed } \\
\text { Value }\end{array}$ \\
\hline R\&D & 17.093 & 17.863 & 18.700 & 17.970 & 1.320 & 8264 \\
CSR & 2.969 & 3.166 & 3.328 & 3.179 & 0.413 & 8264 \\
Media1 & 2.303 & 3.045 & 3.850 & 3.166 & 1.234 & 8264 \\
Media2 & 4.370 & 4.997 & 5.635 & 5.039 & 0.984 & 8264 \\
SOE & 0.000 & 0.000 & 0.000 & 0.090 & 0.286 & 8264 \\
Growth & 1.406 & 1.840 & 2.653 & 2.285 & 1.437 & 8264 \\
Age & 2.000 & 5.000 & 10.000 & 6.768 & 6.362 & 8264 \\
CFO & 0.012 & 0.046 & 0.086 & 0.049 & 0.065 & 8264 \\
Lev & 0.205 & 0.344 & 0.497 & 0.360 & 0.190 & 8264 \\
ESI & 1.000 & 1.000 & 1.000 & 0.824 & 0.381 & 8264 \\
ROA & 17.872 & 18.706 & 19.640 & 18.804 & 1.491 & 8264 \\
Num & 6.791 & 7.494 & 8.352 & 7.636 & 1.206 & 8264 \\
CI & 1.382 & 1.914 & 2.648 & 2.246 & 3.432 & 8264 \\
Size & 21.008 & 21.731 & 22.565 & 21.938 & 1.276 & 8264 \\
\hline
\end{tabular}




\subsubsection{Analysis of Benchmark Return Results}

To avoid spurious regression incurred by the correlation between variables, the VIF test was conducted first, and the mean value of the test result was 2.18, indicating that the selected index data are free of serious multicollinearity. Hence, the next regression analysis was permitted. Model 1 in Table 3 is the test result of regression Equation (1). The CSR coefficient is 0.072 , which is significantly below $1 \%$, indicating that 0.072 units of corporate innovation input can be increased by improving one unit of the enterprise's social score. Model 2 is the test result of regression Equation (2), and the result is that 0.019 units of corporate innovation inputs can be increased by improving one unit of newspaper media reports. Model 3 is the test result of regression Equation (3), and the result shows that 0.036 units of corporate innovation input can be increased by improving one unit of online media report. Model 4 is the test result of Formula (4): CSR coefficient is 0.118, and significant under $1 \%$, indicating that 0.118 units of newspaper media reports can be increased by improving one unit of the CSR index. Model 5 incorporates the variables CSR and Media1 for testing, and the result is still significant. The coefficient direction is still positive, and the coefficient value is basically unchanged, proving that newspaper media reports have formed the mediation mechanism to promote corporate innovation by CSR, thus supporting H1. Models 6 and 7 are the test result of the mediation effect of online media reports on CSR promoting corporate innovation; the CSR coefficient in Model 6 is positive but insignificant, whereas CSR and the Media2 coefficient in Model 7 are significant and positive. According to the mediation effect test procedures, the Sobel test was required by taking Media 2 as the mediation variable, CSR as the independent variable, and R\&D as the dependent variable. According to the Sobel test result, the direct effect (DE) and indirect effect (IDE) for CSR to pass Media2 on R\&D are 0.060 and 0.073 , respectively, which are all significant at $<1 \%$. The RIT value shows that the mediation effect is $45.3 \%$ and the general Sobel test value is 0.000 , proving that online media reports exert a mediation effect on promoting corporate innovation by CSR. To verify the conclusion, the mediating structure equation was adopted again, and the result is consistent with the Sobel test result. To summarize, the mediation path of online media for promoting corporate innovation with CSR was established, and hypothesis $\mathrm{H} 2$ is supported. As shown in Figure 2, the mediation mechanism of corporate innovation promoted by CSR in newspaper and online media reports is established. The rest control variable symbols conform to previous research conclusions: the state-held enterprises lack a reasonable profit-sharing mechanism, and the input and incomes gained by managers within their tenure are unmatched [41], resulting in enterprises maintaining previous routines, with no desire to advance further, shrinking the innovation space. The longer an enterprise lasts, the more stable it becomes, losing its original vigor at the beginning of its establishment [42], which can be caused by the nature of an enterprise and negative duration. A negative asset-liability ratio means that enterprises with high debt-financing ratio have lower corporate innovation input; higher capital intensity results in relatively average profits, less profit, and corporate innovation input [17]. If the indicators measuring the operating status of a company are all positive, including the growth, cash flow, excusive shareholding, and business profit, corporate innovation input can be promoted, agreeing with Wu et al.'s [43] research conclusions. If both the quantity of employees and total assets measuring enterprise scale are positive, the larger the enterprise scale, the higher the corporate innovation input level [44]. 
Table 3. Benchmark regression results.

\begin{tabular}{|c|c|c|c|c|c|c|c|}
\hline Variable & $\begin{array}{c}(1) \\
R \& D\end{array}$ & $\begin{array}{c}(2) \\
R \& D\end{array}$ & $\begin{array}{c}(3) \\
R \& D\end{array}$ & $\begin{array}{c}(4) \\
\text { Media1 }\end{array}$ & $\begin{array}{c}(5) \\
\text { R\&D }\end{array}$ & $\begin{array}{c}(6) \\
\text { Media2 }\end{array}$ & $\begin{array}{c}(7) \\
\text { R\&D }\end{array}$ \\
\hline CSR & $\begin{array}{c}0.072 * * * \\
(0.025)\end{array}$ & & & $\begin{array}{c}0.118^{* * *} \\
(0.032)\end{array}$ & $\begin{array}{c}0.070^{* * *} \\
(0.025)\end{array}$ & $\begin{array}{c}0.020 \\
(0.024)\end{array}$ & $\begin{array}{c}0.071^{* * *} \\
(0.025)\end{array}$ \\
\hline Media1 & & $\begin{array}{l}0.019 * * \\
(0.008)\end{array}$ & & & $\begin{array}{l}0.018^{* *} \\
(0.008)\end{array}$ & & \\
\hline Media2 & & & $\begin{array}{c}0.036^{* * *} \\
(0.011)\end{array}$ & & & & $\begin{array}{c}0.035^{* * *} \\
(0.011)\end{array}$ \\
\hline SOE & $\begin{array}{l}-0.006 \\
(0.031)\end{array}$ & $\begin{array}{l}-0.002 \\
(0.031)\end{array}$ & $\begin{array}{l}-0.001 \\
(0.031)\end{array}$ & $\begin{array}{l}-0.070 \\
(0.040)\end{array}$ & $\begin{array}{l}-0.004 \\
(0.031)\end{array}$ & $\begin{array}{l}-0.054 \\
(0.030)\end{array}$ & $\begin{array}{l}-0.004 \\
(0.031)\end{array}$ \\
\hline Growth & $\begin{array}{c}0.077 * * * \\
(0.007)\end{array}$ & $\begin{array}{c}0.075^{* * *} \\
(0.007)\end{array}$ & $\begin{array}{c}0.071^{* * *} \\
(0.007)\end{array}$ & $\begin{array}{c}0.106^{* * *} \\
(0.009)\end{array}$ & $\begin{array}{c}0.075^{* * *} \\
(0.007)\end{array}$ & $\begin{array}{c}0.167^{* * *} \\
(0.007)\end{array}$ & $\begin{array}{c}0.071 * * * \\
(0.007)\end{array}$ \\
\hline Age & $\begin{array}{c}-0.008 \\
* * * \\
(0.002)\end{array}$ & $\begin{array}{c}-0.008 \\
* * * \\
(0.002)\end{array}$ & $\begin{array}{c}-0.008 \\
* * * \\
(0.002)\end{array}$ & $\begin{array}{c}-0.012 \\
* * * \\
(0.002)\end{array}$ & $\begin{array}{c}-0.008 \\
* * * \\
(0.002)\end{array}$ & $\begin{array}{c}-0.016 \\
* * * \\
(0.002)\end{array}$ & $\begin{array}{c}-0.008 \\
* * * \\
(0.002)\end{array}$ \\
\hline $\mathrm{CFO}$ & $\begin{array}{c}0.105 \\
(0.149) \\
\end{array}$ & $\begin{array}{c}0.123 \\
(0.149) \\
\end{array}$ & $\begin{array}{c}0.128 \\
(0.149) \\
\end{array}$ & $\begin{array}{c}0.169 \\
(0.194) \\
\end{array}$ & $\begin{array}{c}0.102 \\
(0.149) \\
\end{array}$ & $\begin{array}{l}-0.054 \\
(0.145)\end{array}$ & $\begin{array}{c}0.107^{* * *} \\
(0.149)\end{array}$ \\
\hline Lev & $\begin{array}{c}-0.334 \\
* * * \\
(0.063)\end{array}$ & $\begin{array}{c}-0.341 \\
* * * \\
(0.063)\end{array}$ & $\begin{array}{c}-0.347 \\
* * * \\
(0.063)\end{array}$ & $\begin{array}{c}0.120 \\
(0.082)\end{array}$ & $\begin{array}{c}-0.336 \\
* * * \\
(0.063)\end{array}$ & $\begin{array}{c}0.215^{* * *} \\
(0.062)\end{array}$ & $\begin{array}{c}-0.341 \\
* * * \\
(0.063)\end{array}$ \\
\hline ESI & $\begin{array}{l}0.054 * * \\
(0.023)\end{array}$ & $\begin{array}{l}0.052 * * \\
(0.023)\end{array}$ & $\begin{array}{l}0.051 * * \\
(0.023)\end{array}$ & $\begin{array}{l}0.077^{* *} \\
(0.030)\end{array}$ & $\begin{array}{l}0.052 * * \\
(0.023)\end{array}$ & $\begin{array}{c}0.075^{* * *} \\
(0.023)\end{array}$ & $\begin{array}{l}0.051 * * \\
(0.023)\end{array}$ \\
\hline ROA & $\begin{array}{c}0.060 * * * \\
(0.011)\end{array}$ & $\begin{array}{c}0.071 \text { *** } \\
(0.010)\end{array}$ & $\begin{array}{c}0.070^{* * *} \\
(0.010)\end{array}$ & $\begin{array}{c}0.067^{* * *} \\
(0.014)\end{array}$ & $\begin{array}{c}0.058^{* * *} \\
(0.011)\end{array}$ & $\begin{array}{c}0.074^{* * *} \\
(0.011)\end{array}$ & $\begin{array}{c}0.057^{* * *} \\
(0.011)\end{array}$ \\
\hline Num & $\begin{array}{c}0.295^{* * *} \\
(0.014)\end{array}$ & $\begin{array}{c}0.291^{* * *} \\
(0.014)\end{array}$ & $\begin{array}{c}0.293^{* * *} \\
(0.014)\end{array}$ & $\begin{array}{c}0.194^{* * *} \\
(0.018)\end{array}$ & $\begin{array}{c}0.291^{* * *} \\
(0.014)\end{array}$ & $\begin{array}{c}0.025 \\
(0.014)\end{array}$ & $\begin{array}{c}0.294 * * * \\
(0.014)\end{array}$ \\
\hline $\mathrm{CI}$ & $\begin{array}{l}-0.015 \\
* * * \\
(0.003)\end{array}$ & $\begin{array}{c}-0.015 \\
* * * \\
(0.003)\end{array}$ & $\begin{array}{l}-0.015 \\
* * * \\
(0.003)\end{array}$ & $\begin{array}{c}0.001 \\
(0.003)\end{array}$ & $\begin{array}{l}-0.015 \\
* * * \\
(0.003)\end{array}$ & $\begin{array}{c}0.001 \\
(0.002)\end{array}$ & $\begin{array}{c}-0.105 \\
* * * \\
(0.003)\end{array}$ \\
\hline Size & $\begin{array}{c}0.587^{* * *} \\
(0.018)\end{array}$ & $\begin{array}{c}0.573^{* * *} \\
(0.018)\end{array}$ & $\begin{array}{c}0.567^{* * *} \\
(0.019)\end{array}$ & $\begin{array}{c}0.386^{* * *} \\
(0.024)\end{array}$ & $\begin{array}{c}0.580^{* * *} \\
(0.019)\end{array}$ & $\begin{array}{c}0.376^{* * *} \\
(0.018)\end{array}$ & $\begin{array}{c}0.573 * * * \\
(0.019)\end{array}$ \\
\hline Constant & $\begin{array}{c}1.484^{* * *} \\
(0.257)\end{array}$ & $\begin{array}{c}1.771^{* * *} \\
(0.263)\end{array}$ & $\begin{array}{c}1.801^{* * *} \\
(0.260)\end{array}$ & $\begin{array}{c}-8.684 \\
* * * \\
(0.333)\end{array}$ & $\begin{array}{c}1.636^{* * *} \\
(0.267)\end{array}$ & $\begin{array}{c}-5.267 \\
* * * \\
(0.250)\end{array}$ & $\begin{array}{c}1.671^{* * *} \\
(0.264)\end{array}$ \\
\hline Industry & yes & yes & yes & yes & yes & yes & yes \\
\hline Time & yes & yes & yes & yes & yes & yes & yes \\
\hline Obs & 8264 & 8264 & 8264 & 8264 & 8264 & 8264 & 8264 \\
\hline $\mathrm{R}^{2}$ & 0.667 & 0.667 & 0.668 & 0.359 & 0.668 & 0.433 & 0.668 \\
\hline $\mathrm{DE}$ & - & - & - & - & - & \multicolumn{2}{|c|}{$0.060^{* * *}$} \\
\hline IDE & - & - & - & - & - & \multicolumn{2}{|c|}{$0.073^{* * *}$} \\
\hline RIT & - & - & - & - & - & \multicolumn{2}{|c|}{0.453} \\
\hline Sobel & - & - & - & - & - & \multicolumn{2}{|c|}{0.000} \\
\hline
\end{tabular}

The values in brackets are standard errors; ${ }^{* * *}$ and ${ }^{* *}$ indicate significant at the $1 \%$ and $5 \%$ levels, respectively. Industry, industry dummy variable; Time, time dummy variable. 


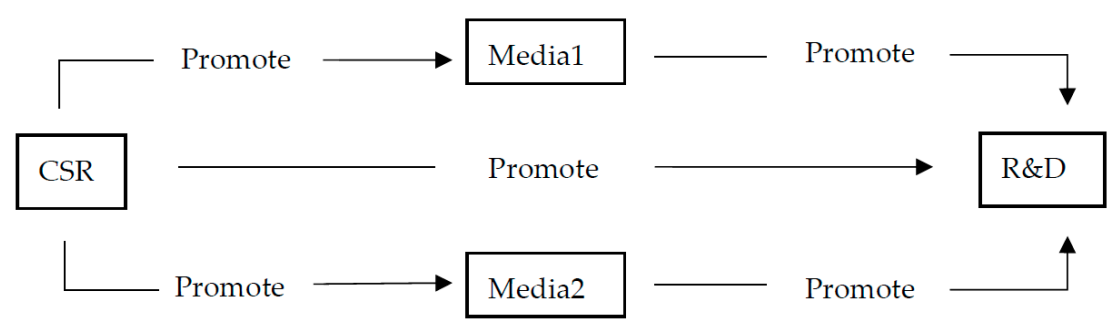

Figure 2. Intermediary mechanism.

\section{Endogenous Test}

With respect to variable omitting problems, they have been solved in this paper by controlling time and industrial variables, but the above test may have disadvantages. First, the data selected are only from companies disclosing their CSR in all samples, i.e., there are sample selection biased errors; second, more innovative enterprises may disclose their social responsibility actively, and trigger lots of media reports, i.e., the endogenous problem of reciprocal causation.

With respect to the first problem, a Heckman stage-2 model is adopted. In stage 1, it is requested to save the sample of undisclosed CSR index in all samples, and define the binary choice variable DCSR, and if the value is 1 for disclosing CSR, the value is 0 for no disclosure. Second, it is requested to establish Probit model considering whether to disclose CSR. Refer to Formula (8):

$$
D C S R_{i t}=\Omega_{0}+\sum \Omega_{i} \text { Controls }_{i t}+\text { Industry }+ \text { Year }+\varepsilon_{i t}
$$

Calculate the inverse mills ratio as per Formula (8), and regard it as the stage- 2 control variable in the regression test of Equations (1)-(7). The test result is as shown in Table 4, while the test procedure corresponds to the above Table 3. According to the result, the conclusion is consistent with the above content.

Table 4. Heckman test results.

\begin{tabular}{|c|c|c|c|c|c|c|c|}
\hline Variable & $\begin{array}{c}(8) \\
\text { R\&D }\end{array}$ & $\begin{array}{c}(9) \\
\text { R\&D }\end{array}$ & $\begin{array}{c}(10) \\
\text { R\&D }\end{array}$ & $\begin{array}{c}\text { (11) } \\
\text { Media1 }\end{array}$ & $\begin{array}{c}(12) \\
\text { R\&D }\end{array}$ & $\begin{array}{c}\text { (13) } \\
\text { Media2 }\end{array}$ & $\begin{array}{c}(14) \\
\text { R\&D }\end{array}$ \\
\hline CSR & $\begin{array}{c}0.065^{* * *} \\
(0.024)\end{array}$ & & & $\begin{array}{c}0.115^{* * *} \\
(0.032)\end{array}$ & $\begin{array}{c}0.066^{* * *} \\
(0.025)\end{array}$ & $\begin{array}{c}0.013 \\
(0.024)\end{array}$ & $\begin{array}{c}0.067^{* * *} \\
(0.024)\end{array}$ \\
\hline Media1 & & $\begin{array}{l}0.018^{* *} \\
(0.008)\end{array}$ & & & $\begin{array}{l}0.017^{* *} \\
(0.008)\end{array}$ & & \\
\hline Media2 & & & $\begin{array}{c}0.034^{* * *} \\
(0.011)\end{array}$ & & & & $\begin{array}{c}0.033^{* * *} \\
(0.011)\end{array}$ \\
\hline Constant & $\begin{array}{c}0.022 \\
(0.302)\end{array}$ & $\begin{array}{c}0.373 \\
(0.312)\end{array}$ & $\begin{array}{c}0.386^{* * *} \\
(0.307)\end{array}$ & $\begin{array}{c}-8.690^{* * *} \\
(0.400)\end{array}$ & $\begin{array}{c}0.247 \\
(0.315)\end{array}$ & $\begin{array}{c}-5.178^{* * *} \\
(0.300)\end{array}$ & $\begin{array}{c}0.263 \\
(0.310)\end{array}$ \\
\hline Controls & yes & yes & yes & yes & yes & yes & yes \\
\hline Industry & yes & yes & yes & yes & yes & yes & yes \\
\hline Time & yes & yes & yes & yes & yes & yes & yes \\
\hline Obs & 8440 & 8251 & 8314 & 8251 & 8251 & 8314 & 8314 \\
\hline $\mathrm{R}^{2}$ & 0.671 & 0.670 & 0.670 & 0.358 & 0.670 & 0.435 & 0.671 \\
\hline $\mathrm{DE}$ & - & - & - & - & - & \multicolumn{2}{|c|}{$0.060^{* * *}$} \\
\hline IDE & - & - & - & - & - & \multicolumn{2}{|c|}{$0.073^{* * *}$} \\
\hline RIT & - & - & - & - & - & \multicolumn{2}{|c|}{0.453} \\
\hline Sobel & - & - & - & - & - & \multicolumn{2}{|c|}{0.000} \\
\hline
\end{tabular}

The values in brackets are standard errors; ${ }^{* * *}$ and ${ }^{* *}$ indicate significant at the $1 \%$ and $5 \%$ levels, respectively Industry, industry dummy variable; Time, time dummy variable. 
With respect to the second problem, this paper adopts preposition stage 1 treatment for independent variable CSR, Media1 and Media2, and denote them as F. CSR, F. Media1, F. Media2, for example, the corporate innovation in 2019 will not promote the CSR disclosure in 2018, while the corporate innovation in 2019 will not cause the media report in 2018 , to avoid the endogenous problem of reciprocal causation reasonably. Model 15 and 16 in Table 5 are, respectively, the test result of merely converting Media1 and Media2 into F. Media1, F. Media2, while Model 17 and 18 are the test results of merely converting CSR into F. CSR, and Model 19 reports the test result of including F. CSR and F. Media1, while Model 20 reports the test result of including F. CSR and F. Media2. No coefficient symbols are found to have directional changes, and are all significant under $1 \%$, which is consistent with the above conclusion.

Table 5. Test results in pre-stage.

\begin{tabular}{|c|c|c|c|c|c|c|}
\hline Variable & $\begin{array}{c}(15) \\
\text { R\&D }\end{array}$ & $\begin{array}{c}(16) \\
\text { R\&D }\end{array}$ & $\begin{array}{c}(17) \\
\text { R\&D }\end{array}$ & $\begin{array}{c}(18) \\
\text { R\&D }\end{array}$ & $\begin{array}{c}(19) \\
\text { R\&D }\end{array}$ & $\begin{array}{c}(20) \\
\text { R\&D }\end{array}$ \\
\hline CSR & $\begin{array}{c}0.080 * * * \\
(0.029)\end{array}$ & $\begin{array}{c}0.083^{* * *} \\
(0.029)\end{array}$ & & & & \\
\hline F.CSR & & & $\begin{array}{c}0.083^{* * *} \\
(0.029)\end{array}$ & $\begin{array}{c}0.087^{* * *} \\
(0.029)\end{array}$ & $\begin{array}{c}0.080^{* * *} \\
(0.029)\end{array}$ & $\begin{array}{c}0.084^{* * *} \\
(0.029)\end{array}$ \\
\hline Media1 & & & $\begin{array}{c}0.028^{* * *} \\
(0.011)\end{array}$ & & & \\
\hline F.Media1 & $\begin{array}{c}0.044^{* * *} \\
(0.010)\end{array}$ & & & & $\begin{array}{c}0.043^{* * *} \\
(0.010)\end{array}$ & \\
\hline Media2 & & & & $\begin{array}{c}0.038^{* * *} \\
(0.014)\end{array}$ & & \\
\hline F.Media2 & & $\begin{array}{c}0.066^{* * *} \\
(0.014)\end{array}$ & & & & $\begin{array}{c}0.065^{* * *} \\
(0.014)\end{array}$ \\
\hline Constant & $\begin{array}{c}1.831^{* * *} \\
(0.327)\end{array}$ & $\begin{array}{c}1.777 * * * \\
(0.321)\end{array}$ & $\begin{array}{c}1.662 \text { *** } \\
(0.325)\end{array}$ & $\begin{array}{c}1.614^{* * *} \\
(0.320)\end{array}$ & $\begin{array}{c}1.829 * * * \\
(0.327)\end{array}$ & $\begin{array}{c}1.777^{* * * *} \\
(0.321)\end{array}$ \\
\hline Controls & yes & yes & yes & yes & yes & yes \\
\hline Industry & yes & yes & yes & yes & yes & yes \\
\hline Time & yes & yes & yes & yes & yes & yes \\
\hline Obs & 5017 & 5017 & 5017 & 5017 & 5017 & 5017 \\
\hline $\mathrm{R}^{2}$ & 0.695 & 0.695 & 0.694 & 0.694 & 0.695 & 0.695 \\
\hline
\end{tabular}

The values in brackets are standard errors; ${ }^{* * *}$ and ${ }^{* *}$ indicate significant at the $1 \%$ and $5 \%$ levels, respectively Industry, industry dummy variable; Time, time dummy variable.

\section{Robustness Test and Extended Analysis}

\subsection{Robustness Test}

To prove the robustness of the research conclusion, the following test is conducted respectively: First, repeat 90\% sample quartile regression with self-help method for 200 times. Second, replace the dependent variable, and replace the corporate innovation input $R \& D$ with the corporate innovation output, i.e., the patent applied by company $i$ in Year $t$, including the invention, utility model, total appearance design patent. Refer to Table 6 Model 21, 22, 23, and 24 for the test result. The test result can conform to the empirical studies above, proving that the above estimated result can pass the robustness test, with rigorous and effective conclusions. 
Table 6. Robustness test.

\begin{tabular}{ccccc}
\hline Variable & $\begin{array}{c}(\mathbf{2 1 )} \\
\text { R\&D }\end{array}$ & $\begin{array}{c}\mathbf{( 2 2 )} \\
\text { R\&D }\end{array}$ & $\begin{array}{c}\text { (23) } \\
\text { Patent }\end{array}$ & $\begin{array}{c}\text { (24) } \\
\text { Patent }\end{array}$ \\
\hline \multirow{2}{*}{ CSR } & $0.060^{* *}$ & $0.061^{* *}$ & $0.154^{* * *}$ & $0.165^{* * *}$ \\
& $(0.027)$ & $(0.031)$ & $(0.042)$ & $(0.042)$ \\
\hline \multirow{2}{*}{ Media1 } & $0.023^{* *}$ & & $0.103 * * *$ \\
& $(0.010)$ & & & \\
\hline \multirow{2}{*}{ Media2 } & & $0.015)$ & $0.080^{* * *}$ \\
\hline Constant & -0.416 & $(0.013)$ & & $(0.019)$ \\
\hline Controls & $(0.454)$ & $(0.440)$ & $(0.457)$ & $-5.070^{* * *}$ \\
\hline Industry & yes & yes & yes & yes \\
\hline Time & no & no & yes & yes \\
\hline Obs & no & no & yes & yes \\
\hline $\mathrm{R}^{2}$ & 8264 & 8264 & 8264 & 8264 \\
\hline
\end{tabular}

The values in brackets are standard errors; ${ }^{* * *}$ and ${ }^{* *}$ indicate significant at the $1 \%$ and $5 \%$ levels, respectively. Industry, industry dummy variable; Time, time dummy variable.

\subsection{Extended Analysis}

\subsubsection{Subdivision of CSR}

CSR grading can be divided into five dimensions by referring to the classification of Hexun.com: Shareholders' responsibility (CSR1), employee responsibility (CSR2), supplier's responsibility (CSR3), environmental responsibility (CSR4), and social contribution responsibility (CSR5). With respect to whether the influence of different responsibility disclosures on corporate innovation is consistent, the test result is as shown in Table 7. According to the result, the disclosure of shareholders' responsibility, employee responsibility, supplier's responsibility and environmental responsibility can benefit corporate innovation input, while the test result of environmental responsibility is not significant, but as can be seen from the coefficient, the influence on corporate innovation is still positive. The employee responsibility can exert the biggest influence on corporate innovation, because for small and medium-sized enterprises, the employee factor is the core impetus to improve corporate innovation input [45]. Model 29 shows that social contribution responsibility restricts corporate innovation, because the performance of such social responsibility cannot take effect on the enterprise within the short-term, and can even occupy relevant resources of the enterprise in technical innovation, and may be regarded as a publicity stunt and rejected by peers, and such complicated interest relation has restricted the corporate innovation input indirectly [45].

Table 7. Subdivision of CSR of different features.

\begin{tabular}{|c|c|c|c|c|c|}
\hline Variable & $\begin{array}{c}(25) \\
\text { R\&D }\end{array}$ & $\begin{array}{c}(26) \\
R \& D\end{array}$ & $\begin{array}{c}(27) \\
R \& D\end{array}$ & $\begin{array}{c}(28) \\
\text { R\&D }\end{array}$ & $\begin{array}{l}\text { (29) } \\
\text { R\&D }\end{array}$ \\
\hline CSR1 & $\begin{array}{c}0.014^{* * *} \\
(0.003)\end{array}$ & & & & \\
\hline CSR2 & & $\begin{array}{c}0.028^{* * *} \\
(0.003)\end{array}$ & & & \\
\hline CSR3 & & & $\begin{array}{l}0.005^{* *} \\
(0.002)\end{array}$ & & \\
\hline CSR4 & & & & $\begin{array}{c}0.002 \\
(0.002)\end{array}$ & \\
\hline
\end{tabular}


Table 7. Cont.

\begin{tabular}{cccccc}
\hline Variable & $\begin{array}{c}(\mathbf{2 5 )} \\
\text { R\&D }\end{array}$ & $\begin{array}{c}\mathbf{( 2 6 )} \\
\text { R\&D }\end{array}$ & $\begin{array}{c}\mathbf{( 2 7 )} \\
\mathbf{R \& D}\end{array}$ & $\begin{array}{c}\mathbf{( 2 8 )} \\
\mathbf{R} \& \mathbf{D}\end{array}$ & $\begin{array}{c}\text { (29) } \\
\text { R\&D }\end{array}$ \\
\hline \multirow{2}{*}{ CSR5 } & & & & $\begin{array}{c}-0.019^{* * *} \\
(0.003)\end{array}$ \\
\hline \multirow{2}{*}{ Constant } & $\begin{array}{c}1.496^{* * *} \\
(0.254)\end{array}$ & $\begin{array}{c}1.961^{* * *} \\
(0.255)\end{array}$ & $\begin{array}{c}1.663^{* * *} \\
(0.254)\end{array}$ & $\begin{array}{c}1.646^{* * *} \\
(0.254)\end{array}$ & $\begin{array}{c}1.666^{* * *} \\
(0.253)\end{array}$ \\
\hline Controls & yes & yes & yes & yes & yes \\
\hline Industry & yes & yes & yes & yes & yes \\
\hline Time & yes & yes & yes & yes & yes \\
\hline Obs & 8264 & 8264 & 8264 & 8264 & 8264 \\
\hline$R^{2}$ & 0.668 & 0.670 & 0.667 & 0.667 & 0.669
\end{tabular}

The values in brackets are standard errors; ${ }^{* * *}$ and ${ }^{* *}$ indicate significant at the $1 \%$ and $5 \%$ levels, respectively. Industry, industry dummy variable; Time, time dummy variable.

\subsubsection{Subdivision of Online Newspaper Media Report of Different Natures}

To further test the influence of newspaper media reports of different natures on corporate innovation, newspaper media reports are subdivided into positive reports (Media11), neutral reports (Media12) and negative reports (Media13), and the test result is as shown in Table 8. According to the result, corporate innovation can be promoted by CSR disclosure under different natures of media reports; The increase of positive reports can promote corporate innovation significantly; The coefficient result of neutral reports and negative reports is not significant, but as can be seen from the symbol direction and size, it is as expected, and neutral reports can also promote corporate innovation, but the influence is weaker than positive reports, while negative reports restrict corporate innovation, proving the "market pressure hypothesis".

Table 8. Subdivision of newspaper media report.

\begin{tabular}{|c|c|c|c|}
\hline Variable & $\begin{array}{c}(30) \\
R \& D\end{array}$ & $\begin{array}{c}(31) \\
\text { R\&D }\end{array}$ & $\begin{array}{c}(32) \\
R \& D\end{array}$ \\
\hline CSR & $\begin{array}{c}0.069 * * * \\
(0.025)\end{array}$ & $\begin{array}{c}0.070^{* * *} \\
(0.025)\end{array}$ & $\begin{array}{c}0.072^{* * *} \\
(0.025)\end{array}$ \\
\hline Media11 & $\begin{array}{c}0.027 * * * \\
(0.008)\end{array}$ & & \\
\hline Media12 & & $\begin{array}{c}0.013 \\
(0.008)\end{array}$ & \\
\hline Media13 & & & $\begin{array}{l}-0.007 \\
(0.009)\end{array}$ \\
\hline Constant & $\begin{array}{c}1.745^{* * *} \\
(0.269)\end{array}$ & $\begin{array}{c}1.592 * * * \\
(0.266)\end{array}$ & $\begin{array}{c}1.429 * * * \\
(0.268)\end{array}$ \\
\hline Controls & yes & yes & yes \\
\hline Industry & yes & yes & yes \\
\hline Time & yes & yes & yes \\
\hline Obs & 8264 & 8264 & 8264 \\
\hline $\mathrm{R}^{2}$ & 0.668 & 0.668 & 0.668 \\
\hline
\end{tabular}

The values in brackets are standard errors; ${ }^{* * *}$ and ${ }^{* *}$ indicate significant at the $1 \%$ and $5 \%$ levels, respectively. Industry, industry dummy variable; Time, time dummy variable. 


\subsubsection{Subdivision of Online Media Report of Different Natures}

Online media reports can be subdivided to positive reports (Media21), neutral reports (Media22) and negative reports (Media23), and the test result is as shown in Table 9. As can be seen from the coefficient symbols and significance, the conclusion drawn are consistent with that of the newspaper media report, so no more descriptions will be provided here.

Table 9. Subdivision of online media report.

\begin{tabular}{cccc}
\hline Variable & $\mathbf{( 3 3 )}$ & $\mathbf{( 3 4 )}$ & $\mathbf{( 3 5 )}$ \\
& $\mathbf{R} \& \mathbf{D}$ & $\mathbf{R} \& \mathbf{D}$ & $0.072^{* * *}$ \\
CSR & $0.069^{* * *}$ & $0.070^{* * *}$ & $(0.025)$ \\
& $(0.025)$ & $(0.025)$ & \\
\hline \multirow{2}{*}{ Media21 } & $0.074^{* * *}$ & & \\
& $(0.011)$ & 0.013 & -0.001 \\
Media22 & & $(0.010)$ & $(0.010)$ \\
\hline Media23 & & & $1.478^{* * *}$ \\
& & & $(0.263)$ \\
\hline Constant & $1.934^{* * *}$ & $1.584^{* * *}$ & yes \\
\hline Controls & $(0.265)$ & $(0.268)$ & yes \\
\hline Industry & yes & yes & yes \\
\hline Time & yes & yes & 8264 \\
\hline Obs & yes & yes & 0.667
\end{tabular}

The values in brackets are standard errors; ${ }^{* *}$ and ${ }^{* *}$ indicate significant at the $1 \%$ and $5 \%$ levels, respectively. Industry, industry dummy variable; Time, time dummy variable.

\section{Conclusions and Policy Implications}

Based on the data from China, this paper provides an investigation on the mediation role of media reports in promoting corporate innovation via CSR disclosure from the perspective of mediation conduction. The key conclusions are as follows.

1. It is confirmed that CSR disclosure can promote corporate innovation significantly;

2. Both newspaper and online media reports can positively influence corporate innovation;

3. CSR disclosure activities can increase the frequency of newspaper and online media reports;

4. Newspaper and online media reports exert a mediating effect in promoting corporate innovation by CSR disclosure.

Further analysis on the individual role of the five aspects of CSR exposures reveals that the performance of public responsibility restricts corporate innovation, since the capital investment made by enterprises to perform the social contribution responsibility may "squeeze out" corporate innovation input in a short time, although a positive promoting effect can be achieved after profits are sustainable in the long-term [46].

Newspaper media and online media reports can be divided into positive, neutral, and negative reports. According to our investigation, CSR disclosure can exert a positive effect on corporate innovation, whereas positive reports can significantly promote corporate innovation. Although neutral and negative reports are not significant in the statistics, negative reports can restrict corporate innovation from the perspective of coefficients, conforming to the market pressure hypothesis. The nature of media reports should be distinguished when studying the influence of media reports on enterprises.

Our study has at least three policy implications: First, the performance of CSR seems to conflict with corporate innovation, and the capital expenditures by an enterprise for 
performing social responsibility will decrease the capital input to corporate innovation, but according to our study, the corporate governance effect can be exerted by actively performing corporate social responsibilities. Enterprises should start internally by maintaining an excellent enterprise image, actively participating in CSR, adhering to the concept of "from the society, and apply in the society", taking advantage of the media preference to report on CSR performance, combining interests with long-term suitable development, and effectively promoting long-term corporate innovation.

Second, both newspaper and online media reports can significantly influence corporate innovation. Even if negative reports are more attractive, media should accurately play its role as an external supervisor by reporting objectively and truthfully to reflect the actual information about the enterprise, and not only seek clicks and distort the facts. Additionally, a supervisory department should also be established in the media to prevent media workers from colluding with enterprises and forming mutual benefit relations.

Third, government incentives and restrictions are equally important. On one hand, the government should strengthen the guidance leading enterprises to actively disclose and perform CSR as well as provide policy guarantees and convenience for possible short-term innovation restrictions. Conversely, "green" media operations should be ensured, while stricter media supervision is required, with the punishment of illegal media, so that the media can better work as the bridge between performing CSR and corporate innovation, and better serve the national innovation strategy.

Although we comprehensively considered newspaper and online media, and investigated the report nature by classification, media reports were not further divided into "breaking" or "false" reports due to the labor force and material limitations. We think that the function of media in companies can be further investigated if media reports can be classified on a deeper level.

Author Contributions: Conceptualization, S.W. and H.Z.; methodology, S.W. and H.Z.; software, H.Z.; validation, S.W. and H.Z.; formal analysis, H.Z.; investigation, S.W.; resources, S.W.; data curation, H.Z.; writing—original draft preparation, H.Z.; writing—review and editing, S.W., H.Z. and T.W.; visualization, H.Z.; supervision, S.W. and T.W.; project administration, S.W.; funding acquisition, S.W. All authors have read and agreed to the published version of the manuscript.

Funding: This work was supported by the Shandong Provincial Colleges and Universities Youth Innovation and Technology Support Program Project (No. 2020RWE005).

Institutional Review Board Statement: Not applicable.

Informed Consent Statement: Not applicable.

Data Availability Statement: The Stata codes for this study can be provided by the authors under request. The original data used in this study are accessible at: https: / / www.gtarsc.com (data of listed companies, accessed on 16 June 2021), http:/ / stockdata.stock.hexun.com/zrbg/Plate.aspx (data of CSR, accessed on 16 June 2021), and https:/ / www.cnrds.com (Data of media reports, accessed on 16 June 2021).

Acknowledgments: We are grateful for the comments from the three anonymous reviewers.

Conflicts of Interest: The authors declare no conflict of interest.

\section{References}

1. Halkos, G.; Skouloudis, A. Corporate social responsibility and innovative capacity: Intersection in a macro-level perspective. J. Clean. Prod. 2018, 182, 291-300. [CrossRef]

2. Castilla-Polo, F.; Sánchez-Hernández, M.I.; Gallardo-Vázquez, D. Assessing the influence of social responsibility on reputation: An empirical Case-Study in agricultural cooperatives in Spain. J. Agric. Environ. Ethics 2017, 30, 99-120. [CrossRef]

3. Lončar, D.; Paunković, J.; Jovanović, V.; Krstić, V. Environmental and social responsibility of companies cross EU countries-Panel data analysis. Sci. Total Environ. 2019, 657, 287-296. [CrossRef]

4. $\mathrm{Xu}, \mathrm{H}$. Corporate social responsibility, product innovation, and product line. Nankai Bus. Rev. Int. 2020, 11, 171-190. [CrossRef]

5. Grover, P.; Kar, A.K.; Ilavarasan, P.V. Impact of corporate social responsibility on reputation-Insights from tweets on sustainable development goals by CEOs. Int. J. Inf. Manag. 2019, 48, 39-52. [CrossRef] 
6. Li, G.; Yan, K.; Wei, Z.; Cheng, T. Can Servitization Enhance Customer Loyalty? The Roles of Organizational IT, Social Media, and Service-Oriented Corporate Culture. IEEE Trans. Eng. Manag. 2021, 1-15. [CrossRef]

7. Camilleri, M.A.; Rui, A.C. The Small Businesses' Responsible Entrepreneurship and their Stakeholder Engagement through Digital Media. In Proceedings of the 13th European Conference on Innovation and Entrepreneurship (ECIE), Aveiro, Portugal, 20-21 September 2018.

8. Ahern, K.R.; Sosyura, D. Rumor has it: Sensationalism in financial media. Rev. Financ. Stud. 2015, 28, 2050-2093. [CrossRef]

9. Liu, B.; McConnell, J.J. The role of the media in corporate governance: Do the media influence managers' capital allocation decisions? J. Financ. Econ. 2013, 110, 1-17. [CrossRef]

10. Lin, Y.-E.; Li, Y.-W.; Cheng, T.Y.; Lam, K. Corporate social responsibility and investment efficiency: Does business strategy matter? Int. Rev. Financ. Anal. 2021, 73, 101585. [CrossRef]

11. Luo, W.; Guo, X.; Zhong, S.; Wang, J. Environmental information disclosure quality, media attention and debt financing costs: Evidence from Chinese heavy polluting listed companies. J. Clean. Prod. 2019, 231, 268-277. [CrossRef]

12. Hung, M.; Shi, J.; Wang, Y. The Effect of Mandatory CSR Disclosure on Information Asymmetry: Evidence from a Quasi-Natural Experiment in China. Soc. Sci. Electron. Publ. 2013, 33, 1-17. [CrossRef]

13. Hu, W.; Du, J.; Zhang, W. Corporate social responsibility information disclosure and innovation sustainability: Evidence from China. Sustainability 2020, 12, 409. [CrossRef]

14. Costa, C.; Lages, L.F.; Hortinha, P. The bright and dark side of CSR in export markets: Its impact on innovation and performance. Int. Bus. Rev. 2015, 24, 749-757. [CrossRef]

15. Yu, F.; Shi, Y.; Wang, T. R\&D Investment and Chinese Manufacturing SMEs Corporate Social Responsibility: The Moderating Role of Regional Innovative Milieu. J. Clean. Prod. 2020, 258, 120840.

16. Cheng, B.; Ioannou, I.; Serafeim, G. Corporate social responsibility and access to finance. Strateg. Manag. J. 2014, 35, 1-23. [CrossRef]

17. Yang, J. Corporate Social Responsibility Disclosure and Innovation Performance: An Empirical Study—Based on Chinese Listed Firms during "the Post-mandatory Period". Sci. Sci. Manag. S \& T 2021, 42, 57-75.

18. Hutton, A.P.; Marcus, A.J.; Tehranian, H. Opaque financial reports, R2, and crash risk. J. Financ. Econ. 2009, 94, 67-86. [CrossRef]

19. Zhao, Y.; Qin, Y.; Zhao, X.; Wang, X.; Shi, L. Perception of corporate hypocrisy in China: The roles of corporate social responsibility implementation and communication. Front. Psychol. 2020, 11, 595. [CrossRef] [PubMed]

20. Huang, J.; Chen, L.; Ding, J. Corporate social responsibility, mediacoverage and stock pricecrash risk. Chin. J. Manag. Sci. 2021, 29, $1-12$.

21. Tian, L.; Wang, K. The "masking effect" of social responsibility information disclosure and the risk of listed companies' collapse: DID-PSM analysis from China's stock market. Manag. World 2017, 11, 146-157.

22. Kuo, L.; Kuo, P.-W.; Chen, C.-C. Mandatory CSR Disclosure, CSR Assurance, and the Cost of Debt Capital: Evidence from Taiwan. Sustainability 2021, 13, 1768. [CrossRef]

23. Dai, L.; Shen, R.; Zhang, B. The dark side of news coverage: Evidence from corporate innovation. Unpubl. wp. 2015. Available online: https:/ / acfr.aut.ac.nz/_data/assets/pdf_file/0005/29723/581119-R-Shen-News-Coverage-and-Corporate-Innovation20150226.pdf (accessed on 16 June 2021).

24. Hayes, R.A.; Carr, C.T. Getting called out: Effects of feedback to social media corporate social responsibility statements. Public Relat. Rev. 2021, 47, 101962. [CrossRef]

25. Lu, W.; Yanxi, L.; Xiaochong, L. Corporate social responsibility disclosure, media coverage and financial performance: An empirical analysis in the chinese context. Singap. Econ. Rev. 2020, 1-18. [CrossRef]

26. Xiang, X.; Liu, C.; Yang, M.; Zhao, X. Confession or justification: The effects of environmental disclosure on corporate green innovation in China. Corp. Soc. Responsib. Environ. Manag. 2020, 27, 2735-2750. [CrossRef]

27. Gupta, S.; Nawaz, N.; Tripathi, A.; Muneer, S.; Ahmad, N. Using Social Media as a Medium for CSR Communication, to Induce Consumer-Brand Relationship in the Banking Sector of a Developing Economy. Sustainability 2021, 13, 3700. [CrossRef]

28. Xu, L.; Xin, Y.; Zhu, J. Media attention and the fulfillment of social responsibilities of listed companies: An empirical study based on donations from the Wenchuan earthquake. Manag. World 2011, 3, 135-143, 188.

29. He, Y.; Zhao, C. Impact of media reports on innovative behaviours of photovoltaic enterprises: Experience view from China. Light Eng. 2018, 26, 129-138. [CrossRef]

30. Liu, J.; Li, R. Research on the Influence of Media Attention on the Innovation Behavior of Publishing Enterprises. China Publ. J. 2019, 22, 11-17.

31. Wang, M.-C. The relationship between environmental information disclosure and firm valuation: The role of corporate governance. Qual. Quant. 2016, 50, 1135-1151. [CrossRef]

32. Zhang, Y.; Peng, S. Media Attention and Enterprise Innovation Performance. J. Guizhou Univ. Financ. Econ. 2020, 4, $29-39$.

33. Zhao, Y.; Chen, Z.; Li, C. Research of the Influencing Mechanism of External Knowledge Acquisition \& Social Media on Firm Innovation Based on Open Innovation Perspective. Forecasting 2020, 39, 1-8.

34. Jin, X.; Yu, J. Government governance, executive networks and corporate investment efficiency. China Financ. Rev. Int. 2018, 8, 122-139. [CrossRef]

35. Li, X.; Li, C.; Wang, Z.; Jiao, W.; Pang, Y. The effect of corporate philanthropy on corporate performance of Chinese family firms: The moderating role of religious atmosphere. Emerg. Mark. Rev. 2020, 1, 100757. [CrossRef] 
36. Zhao, L.; Zhang, L. The Impact of Media Coverage on Enterprise Green Technology Innovation: The Moderating role of Marketization Level. Manag. Rev. 2020, 32, 132-141.

37. Luo, J.; Liu, Q. Corporate social responsibility disclosure in China: Do managerial professional connections and social attention matter? Emerg. Mark. Rev. 2020, 43, 100679. [CrossRef]

38. Zhou, K.; Ying, Q.; Chang, Z. Can media coverage improve corporate governance? evidence from fraud by listed firms in China. J. Financ. Res. 2016, 6, 193-206.

39. Li, F.; Geng, X. Research on the Relationship between Environmental Uncertainty Perceived by CEO and Enterprise Choice of Innovation Mode. Sci. Technol. Prog. Policy 2021, 38, 1-10.

40. Yang, D.; Chen, H.; Liu, Q. Media Pressure and Corporate Innovation. Econ. Res. J. 2017, 52, 125-139.

41. Xu, C.; Zhang, X. Research on the Improvement of State-owned Enterprises' Independent Innovation Ability. Res. Financ. Econ. Issues 2015, 4, 110-116.

42. Yasuda, T. Firm growth, size, age and behavior in Japanese manufacturing. Small Bus. Econ. 2005, 24, 1-15. [CrossRef]

43. Wu, C.; Wu, S.; Cheng, J.; Wang, L. The Role of Venture Capital in the Investment and Financing Behavior of Listed Companies: Evidence from China. Econ. Res. J. 2012, 47, 105-119, 160.

44. Conte, A.; Vivarelli, M. Succeeding in innovation: Key insights on the role of R\&D and technological acquisition drawn from company data. Empir. Econ. 2014, 47, 1317-1340.

45. Duan, J.; Zhuang, X. Research on the Hierarchical Influencing Mechanism of Social Responsibility Performance on Enterprise Innovation Ability: Empirical Evidence Based on Chinese Listed Companies. S. China J. Econ. 2020, 8, 49-64.

46. Ma, H.; Hou, G. Environmental Protection Investment, Financing Constraints, and Enterprise Technological Innovation: A Research Perspective Based on the Impact of Long- and Short-term Heterogeneity. Secur. Mark. Her. 2018, 8, 12-19. 